\title{
COMPUTED TOMOGRAPHY SCAN FOR DIAGNOSIS OF OSTEOARTHRITIS: RARE LOCALIZATION IN THE SHOULDER IN A TWELVE-YEAR-OLD BOY
}

\author{
Dragana Nikolić ${ }^{1}$, Đurđica Milković ${ }^{2}$ and Vladimir Jurišić ${ }^{3}$ \\ ${ }^{1}$ University Hospital of Foča, Department of Radiology, University of East Sarajevo, \\ Foča, Republika Srpska, Bosnia and Herzegovina; \\ ${ }^{2}$ Srebrnjak Children's Hospital, Zagreb, Croatia; ${ }^{3}$ Faculty of Medical Sciences, \\ University of Kragujevac, Kragujevac, Serbia
}

\begin{abstract}
SUMMARY - Acute osteomyelitis is pyogenic infection of the bone and bone marrow. We report a case of successful diagnosis and treatment in a 12-year-old boy with right shoulder joint osteoarthritis. On admission, he was febrile $\left(39.0^{\circ} \mathrm{C}\right)$ with pain in his right shoulder. Laboratory and biochemistry findings were as follows: leukocytes $10.9 \times 10^{9} / \mathrm{L}$; hemoglobin $122 \mathrm{~g} / 1$; fibrinogen 34.7; C-reactive protein 56.8. No changes were observed using conventional radiography. Computed tomography (CT) scan was conducted on the right limb using LightSpeed 16 slices in native and contrast series. The area of interest was shown on axial section, less dense fluid within the joint cavity with a thickened capsule and joint soft tissue swelling around the joint. On bone structures, CT morphological changes were not observed. After deterioration of the condition despite antibiotic therapy, surgery had to be performed. The purulent content was removed by surgery. Prolonged antibiotic therapy and rehabilitation led to improvement of the condition. At two-month follow-up, ultrasonography and CT scan showed that there were no pathologic changes, while magnetic resonance imaging showed minimal tissue fibrosis that did no require surgical treatment.
\end{abstract}

Key words: Osteoarthritis; Osteomyelitis; Septic arthritis; Shoulder joint; Child; Diagnosis, methods; Therapy

\section{Introduction}

Acute osteomyelitis is a pyogenic bone and bone marrow infection, while septic arthritis is a joint inflammation caused by the same agent $t^{1,2}$. Due to the association of both these clinical entities, a joint term named 'osteoarthritis' has been coined, which undoubtedly points to inflammation changes in both joint segments. A dominant manner of spreading infection is hematogenous, especially in children ${ }^{3}$. The predictive sites of outbreak are long bone endosteum, especially lower extremities (knee, hip). The hip has a major share of $75 \%$

Correspondence to: Prof. Vladimir Jurišic, $M D, P h D$, Faculty of Medical Sciences, University of Kragujevac, Kragujevac, Serbia

E-mail: jurisicvladimir@gmail.com

Received September 26, 2016, accepted February 13, 2017 of the sites of outbreak in all studied cases, followed by the knee, while shoulder joint has a share of $4 \%$ in the studied cases $^{1,4}$. In general, septic osteoarthritis is a severe pathologic condition. Any delay in diagnosis and treatment leads to heavy and most often irreversible sequels, and potentially to disability. Risk factors of inaccurate prognosis are up to six months of age, misdiagnosis, delay in the course of treatment, and Staphylococcus aureus infection ${ }^{4-6}$. We present a case of successful diagnosis and treatment in a 12-year-old boy with right shoulder joint osteoarthritis.

\section{Case Report}

A 12-year-old boy (body weight $44 \mathrm{~kg}$, body height $152 \mathrm{~cm}$ ) was febrile, eupneic in resting conditions, 

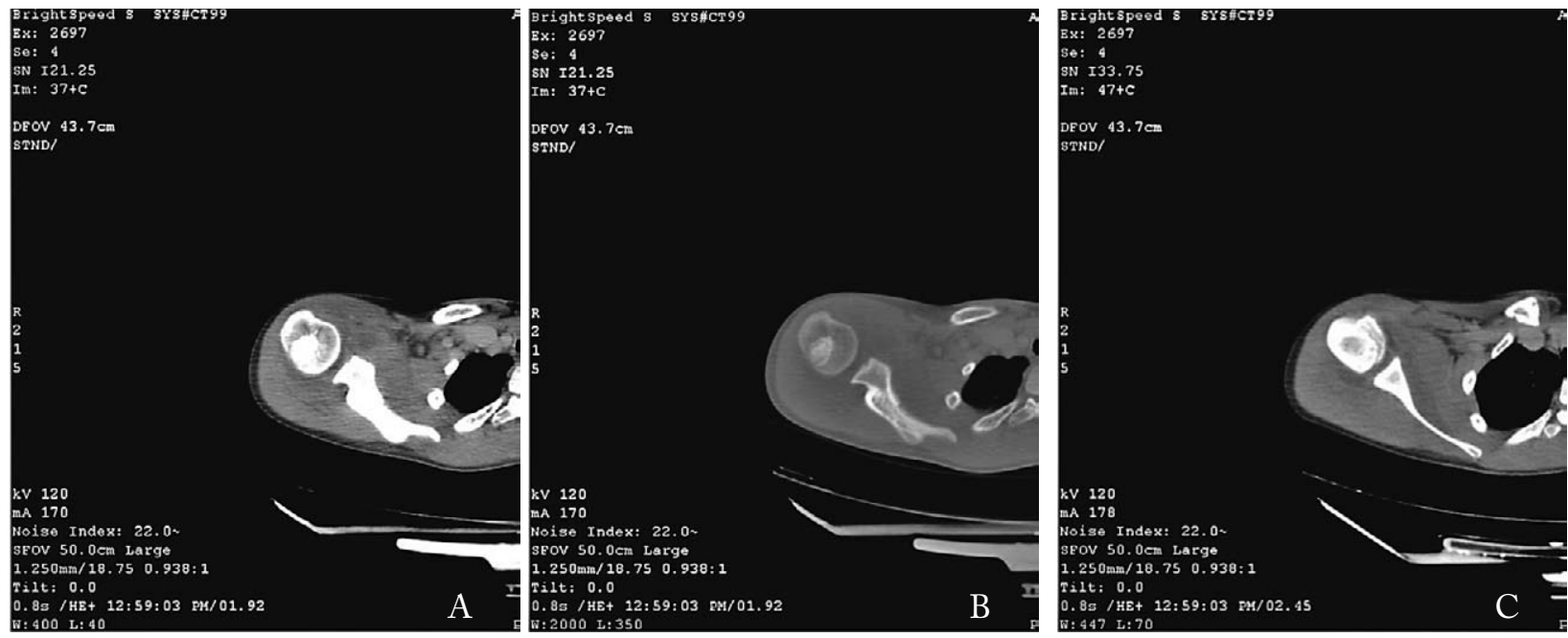

Fig. 1. Computed tomography $(C T)$ of the right shoulder: differential fluid in the joint with soft tissue swelling without significant $C T$ changes in the bone structures $(A, B, C)$.

normocardic, with pain in the right shoulder that occurred in the morning after one hour of exercise. The pain increased with movement and spread across the front side of the upper arm, followed by high temperature, up to $39.0^{\circ} \mathrm{C}$. Laboratory results were as follows: erythrocyte sedimentation rate (ESR) 11/29; leukocytes 10.9; red blood cells (RBC) 4.4; hemoglobin 122 g/L; fibrinogen 34.7; C-reactive protein (CRP) 56.8; antistreptolysin $\mathrm{O}$ titer (ASTO) negative; rheumatoid factor (RF) negative; ALT $53 \mathrm{U} / \mathrm{L} ;$ AST $56 \mathrm{U} / \mathrm{L} ; \mathrm{CK}$ $56 \mathrm{U} / \mathrm{L}$; blood culture negative at the time (probably due to antibiotic treatment administered on the day of admission to the hospital). Right shoulder and knee radiography was without pathologic changes. Right shoulder computed tomography (CT) scan was conducted on GE LightSpeed 16 slices (USA) in native and contrast series. The area of interest was shown on axial section, less dense fluid within the joint cavity (20 $\mathrm{HU})$, with thick joint capsules and periarticular soft tissue swellings. CT morphological changes were not discernable on bone structures (Fig. $1 \mathrm{~A}, \mathrm{~B}, \mathrm{C}$ ).

The patient's treatment started by administering ceftriaxone IV and ibuprofen tablets. After deterioration of the general state and CT results, the patient was administered vancomycin and then referred to the Institute for Mother and Child Health Care in Belgrade, Serbia, for further treatment. After new, repeat laboratory results (CRP 156), surgery was performed (fenestratio humeri dex via metaphisis proximalis). Purulent content was obtained by fenestration; soft bone cortex was highly vascularized. The swab was sterile as expected due to antibiotic treatment the patient received upon the appearance of the first symptoms. After surgery, laboratory results showed a decrease in the values and the patient was subjectively better, occasionally febrile at night. The operative wound did not exhibit any complications. Drains were removed after third postoperative day. Upon removal of temporary immobilization, physical treatment was started until complete joint mobility was achieved. Apart from the aforementioned procedure, the patient was administered vancomycin and gentamicin as antibiotics for three weeks and then Cefzil $500 \mathrm{mg}$ tablets for another one week. Laboratory results showed reference values on patient discharge. Follow-up ultrasound findings obtained two months after surgery did not show any pathologic changes. Magnetic resonance imaging (MRI) examination was conducted six months after surgery, using the MRI Hitachi machine (0.3 T in sequences T1 and T2 was used; STIR), showing minimal fibrosis at the site of fenestration (Fig. 2A, 2B).

\section{Discussion}

Shoulder septic osteoarthritis, which is described in this case report, is very rare, especially in 12-yearold children. Data from some studies report up to $4 \%$ of similar cases of osteoarthritis, which is more common on femur and tibia; however, in our case, we describe a rare localization as well ${ }^{7}$. In our case, the young 

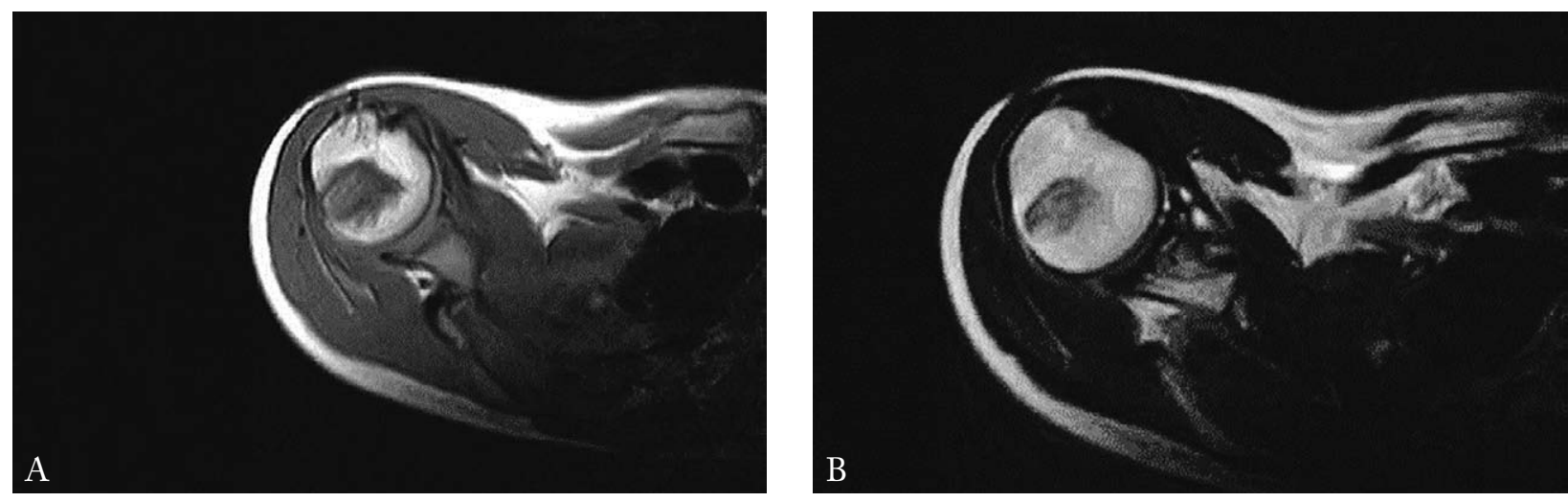

Fig. 2. Magnetic resonance image of the right shoulder (T1 and T2 sequences): minimal fibrosis at the site of fenestration (A); and postoperative scar-superficial (B).

age of the patient was a potentially disturbing factor for accurate diagnosis. Some studies usually describe more seronegative and positive rheumatoid conditions at the given age than septic osteoarthritis ${ }^{7-10}$.

Data from previous studies indicated that septic osteoarthritis was more common in boys, especially among the black population ${ }^{4,5,11}$. The predicative sites of outbreak are long bone metaphyses, as they are highly vascularized and suitable for hematogenous dissemination of the infection. Bacterial embolus affects microcirculation, leading to an increase in intraosseous pressure and consecutively to ischemic bone necrosis and abscess formation. The infection leads to the appearance of joint outflow and leukocyte conglomeration, and further leads to injury of the joint structure ${ }^{6}$.

The most significant cause of septic osteoarthritis is Staphylococcus aureus in people of all ages. Staphylococcus type B and gram-negative bacilli can be found mostly in patients and infants with immune system problems. Methicillin, a resistant type of Staphylococcus, was singled out as the most dominant cause for this condition in recent studies ${ }^{7,8}$. In many cases that can be fatal, the symptomatology and a disorder that occurs first is often unnoticed due to the occurrence of septic temperature in the joint, joint pain and limited movement of the joint.

Clinical examination of a patient as a primary diagnostic tool despite technological progress and availability of various diagnostic modalities is necessary, as demonstrated in the case presented. In addition, basic laboratory parameters, including leukocytes and ESR, were and are still of great importance for the evalua- tion of a patient with suspected septic osteoarthritis, especially if there is no association with other infections.

Standard radiography is important but only two to three weeks after the onset of symptoms, and there is no particular significance in the verification of the acute form ${ }^{9}$. However, it is of great importance for monitoring and evaluation of complications or calcification $^{9,10}$. Ultrasound methods provide exceptional information on the state of soft tissue joint structure, as well as on bone structure, especially in infants. The advantage of ultrasonic methods is that changes can be observed more than $48 \mathrm{~h}$ of the symptom onset ${ }^{10}$. Furthermore, it is useful with diagnostic and therapeutic joint punctures that aim to obtain the material for analysis and evaluation of the pathologic content with minimal trauma, as opposed to surgery.

Computed tomography scan is also applied routinely, and it is primarily informative from the aspect of bone state evaluation. However, in our case, the results of joint space free fluid of higher density values $(25 \mathrm{HU})$ and soft tissue structure swelling in the joint capsule were sufficient, among other results, for diagnosing septic arthritis ${ }^{11,12}$. Since MRI has been described as the gold standard for evaluating the locomotor system, in our case, follow-up MRI examination was conducted seven months after surgery with the aim of evaluating the sequels, considering the patient's age and physical activity. However, the accurate diagnosis of osteoarthritis in this case was based mostly on clinical laboratory results, radiology diagnosis methods, and, in the end, diagnostic and therapeutic operation procedures. 
The steps that had to be taken to treat osteoarthritis are quite clear and include aggressive antibiotic therapy. Given the high level of resistance of the bacterial types that are the most common causes, antibiotic sensitivity report for the causes isolated on blood culture or more often on puncture of the joint contents or drained contents is obligatory ${ }^{7}$. The highest sensitivity for Staphylococcus is shown by vancomycin and clindamycin, therefore they are mostly used in therapy. Therapy is administered for three to six weeks; better response is obtained if medicine is administered IV in-

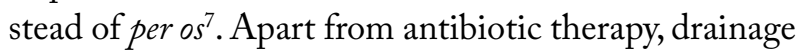
is obligatory if the joint is available, as it was the case in our patient, where besides the perioperative drainage procedure, empirical antibiotic therapy was administered (vancomycin combined with ceftriaxone).

Making an accurate diagnosis of osteoarthritis in the described patient was based on the correlation of clinical and laboratory findings, radiological diagnosis and finally diagnostic-therapeutic surgery.

\section{Conclusion}

Acute osteoarthritis is not a common condition but the diagnosis must be determined quickly, and it requires the use of antibiotics as early as possible, with obligatory joint drainage if possible. Shoulder affection is extremely rare, especially at the given age, but it requires a multidisciplinary approach. This study shows the importance of achieving a timely diagnosis with the help of modern methods that include CT scan to initiate appropriate treatment and prevent the consequences of disease, including deformities and morbidity. In this case, it was sufficient to confirm the diagnosis through CT scan, although it is sometimes necessary to conduct an MRI. Only this type of approach ensures quick and successful recovery without unwanted effects on the growth, development, and function of the joint.

\section{Acknowledgment}

This work was partially supported by grants from the Ministry of Education, Science and Technological
Development of the Republic of Serbia, grant number 175056.

\section{References}

1. De Boeck H. Osteomyelitis and septic arthritis in children. Acta Orthop Belg. 2005;71:505-15.

2. Vukašinović Z, Spasovski D, Čobeljić G, Živković Z. Septični artritis kuka kod dece: mogućnosti dijagnostikovanja i lečenja. Srp Arh Celok Lek. 2006;134(1-2):77-81. (in Serbian)

3. Smith SP, Thyoka M, Lavy CBD, Pitani A. Septic arthritis of the shoulder in children in Malawi: a randomised, prospective study of aspiration versus arthrotomy and washout. J Bone Joint Surg [Br]. 2002;84-B:1167-72. doi: 10.1302/0301-620x. $84 \mathrm{~b} 8.13080$

4. Ernat J, Riccio AI, Fitzpatrick K, Jo C, Wimberly RL. Osteomyelitis is commonly associated with septic arthritis of the shoulder in children. J Pediatr Orthop. 2017;37(8):547-552. doi: 10.1097/BPO.0000000000000709.

5. Schwentker EP. Septic arthritis, pediatrics. last updated: Jan 21. 2009. E-medicine. Available from: http://emedicine.medscape. com/article/1259337-overview.

6. Ibia EO, Imoisili M, Pikis A. Group A beta-hemolytic streptococcal osteomyelitis in children. Pediatrics. 2003;112:22-6. doi: 10.1542/peds.112.1.e22

7. Matić A, Gajdobranski Đ, Petković L, Velisavljev Filipović G, Ristivojević A. Akutni osteomijelitis i septični artritis ramena kod prevremeno rođenog novorođenčeta - prikaz dva slučaja. Med Pregl. 2012;LXV(1-2):59-64. (in Serbian) doi: 10.2298/ MPNS1202059M

8. Offiah AC. Acute osteomyelitis, septic arthritis and discitis: differences between neonates and older children. Eur J Radiol. 2006;60:221-32. doi: 10.1016/j.ejrad.2006.07.016

9. Renton P. Periosteal reactions; bone and joint infections; sarcoidosis ED.1155-1171. In: Sutton D, editor. Textbook of Radiology and Imaging; $7^{\text {th }}$ edn. London: Churchill Livingstone. 2003.

10. Peltola H, Pääkkönen M. Acute osteomyelitis in children. N Engl J Med. 2014;370:352-60. doi: 10.1056/NEJMra1213956

11. Jagodzinski NA, Kanwar R, Graham K, Bache CE. Prospective evaluation of a shortened regimen of treatment for acute osteomyelitis and septic arthritis in children. J Pediatr Orthop. 2009;29:518-25. doi: 10.1097/BPO.0b013e3181ab472d

12. Belthur MV, Birchansky SB, Verdugo AA, et al. Pathologic fractures in children with acute Staphylococcus aureus osteomyelitis. J Bone Joint Surg Am. 2012;94:34-42. doi: 10.2106/ JBJS.J.01915 


\section{Sažetak}

\section{KOMPJUTORIZIRANA TOMOGRAFIJA U DIJAGNOSTICI OSTEOARTRITISA: RIJETKA LOKALIZACIJA U RAMENU KOD 12-GODIŠNJEG DJEČAKA}

\section{Nikolić, Đ. Milković i V. Jurišić}

Akutni osteomijelitis je piogena infekcija kostiju i koštane srži. Ovdje opisujemo klinički slučaj uspješne dijagnoze i liječenja kod 12-godišnjeg dječaka s osteoartritisom desnog ramena. Kod prijma bio je febrilan $\left(39,0{ }^{\circ} \mathrm{C}\right) \mathrm{s}$ bolovima u desnom ramenu. Laboratorijski i biokemijski nalazi bili su sljedeći: leukociti 10,9x109/L; hemoglobin $122 \mathrm{~g} / \mathrm{L}$; fibrinogen 34,7; C-reaktivni protein 56,8. Primjena konvencionalne radiografije nije pokazala promjene. Kompjutorizirana tomografija (CT) je provedena na desnoj ruci koristeći 16-slojni Light Speed uređaj u prirodnoj i kontrastnoj seriji. Ispitivano područje prikazano je na aksijalnom presjeku, unutar zglobne šupljine manje guste tekućine sa zadebljanom kapsulom i zadebljanjem u mekotkivnoj okolini zgloba. Na koštanim strukturama nisu primijećene CT morfološke promjene. Nakon pogoršanja stanja usprkos antibiotskoj terapiji morao se izvršiti operativni zahvat. Gnojni sadržaj uklonjen je operativnim zahvatom. Dugotrajna antibiotska terapija i rehabilitacija doveli su do pobolǰsanja stanja. Nakon dvomjesečnog praćenja, ultrazvuk i CT skeniranje pokazali su da nema patoloških promjena, dok je snimanje magnetskom rezonancom pokazalo minimalnu fibrozu tkiva za koju nije bilo potrebno kirurško liječenje.

Ključne riječi: Osteoartritis; Osteomijelitis; Septički artritis; Rameni zglob; Dijete; Dijagnostika, metode; Terapija 